\title{
Mortality, disease progression, and disease burden of acute kidney injury in alcohol use disorder subpopulation
}

\section{AUTHORS}

Sidney Le BA ${ }^{1}$, Abigail Green-Saxena $\mathrm{PhD}^{1^{*}}$, Jenish Maharjan ${ }^{1}$, Manan Khattar ${ }^{1}$, Jacob Calvert MSc ${ }^{1}, \mathrm{Emily}$ Pellegrini $\mathrm{BS}^{1}$, Jana Hoffman $\mathrm{PhD}^{1}$, Ritankar Das $\mathrm{MSc}^{1}$

${ }^{1}$ Dascena, Inc., Oakland, CA, United States

* Corresponding author

Email: abigail@dascena.com

414 13th St, Suite 500

Oakland, CA 94612

(510) $826-9508$

Funding: This work was funded by a grant from the National Institute on Alcohol Abuse and Alcoholism (NIAAA); grant ID: 1R43AA02767401.

Conflict of Interest Statement: All authors who have affiliations listed with Dascena (Oakland, California, USA) are employees or contractors of Dascena. 
medRxiv preprint doi: https://doi.org/10.1101/2020.01.10.20017061; this version posted January 16, 2020. The copyright holder for this preprint (which was not certified by peer review) is the author/funder, who has granted medRxiv a license to display the preprint in perpetuity.

All rights reserved. No reuse allowed without permission.

\section{ABSTRACT}

Objective: The objective of this study is to quantify the relationship between acute kidney injury (AKI) and alcohol use disorder (AUD), in terms of disease burden, mortality burden and disease progression.

Methods: We used the University of California, San Francisco Medical Center in San Francisco, CA (UCSF) and Medical Information Mart for Intensive Care (MIMIC-III) databases to quantify AKI disease and mortality burden as well as AKI disease progression in the AUD and non-AUD subpopulations. We used the MIMIC-III dataset to compare two different methods of encoding AKI: ICD-9 codes, and the 2012 Kidney Disease: Improving Global Outcomes scheme (KDIGO). In addition to the AUD subpopulation (defined by AUD-related ICD-9 codes), we also present analysis for the hepatorenal syndrome (HRS) and alcohol-related cirrhosis subpopulations identified via ICD-9 coding.

Results: In both the ICD-9 and KDIGO encodings of AKI, the AUD subpopulation had a higher prevalence of AKI (ICD-9: $48.59 \%$ vs. $29.99 \%$ AKI in the non-AUD subpopulations; KDIGO: $39.84 \%$ vs. $27.99 \%$ ) in the MIMIC-III dataset. In the UCSF dataset, the AUD subpopulation also had a higher prevalence of AKI than the non-AUD subpopulation (ICD-9: $48.60 \%$ vs. $8.45 \%$ ). The mortality rate of the subpopulation with both AKI and an AUD-related condition (AUD, HRS, or alcohol-related cirrhosis) was consistently higher than that of the subpopulation with only $\mathrm{AKI}$ in both datasets after adjusting for disease severity using two methods of severity estimation in the MIMIC-III dataset. Disease progression rates were similar for AUD and non-AUD subpopulations.

Conclusions: Our work using the UCSF multi-ward academic hospital data and the MIMIC-III ICU dataset shows that the AUD patient subpopulation had a higher number of AKI patients than the non-AUD subpopulation, and that patients with both AKI and either AUD, HRS, or alcohol-related cirrhosis were shown to have higher rates of mortality than the non-AUD subpopulation with AKI.

Trial Registration: Not applicable.

\section{INTRODUCTION}

Acute kidney injury (AKI; previously referred to as acute renal failure [1]), affects approximately $7 \%$ of all inpatients, up to one-in-five ICU patients, and incurs an annual cost of \$5.4B in the United States [2-5]. AKI is correlated with an increased risk of death [6], and occurs abruptly with a sudden loss of kidney function over the course of several days. AKI treatment involves determining and treating the cause of AKI $[7,8,9]$ in addition to providing supportive treatment until the patient improves.

Alcohol use disorder (AUD), a medical diagnosis for severe problem drinking, is a prevalent and disabling disorder associated with multiple comorbidities [10,11]. Alcohol consumption is reported to be the third most important preventable cause of disease, after smoking and hypertension [12,13], and accounts for $4.2 \%$ of the global burden of disease measured in disability-adjusted life years [12,14]. Although the mechanisms through which AUD might directly lead to AKI are not clearly defined [15], alcohol abuse can result in alcohol-related cirrhosis [16] and alcoholic hepatitis [17,18], conditions that leave patients particularly vulnerable to AKI [1,19]. Hepatorenal syndrome (HRS), characterized by circulatory dysfunction and renal failure, is a common complication of cirrhosis and alcoholic hepatitis with poor prognosis [20,21]. Approximately $75 \%$ of patients with cirrhosis develop renal dysfunction, which is considered a prominent cause of morbidity and mortality in this patient population [22,23], and approximately $20 \%$ of patients hospitalized with cirrhosis develop AKI [1]. 
Taken together, these data suggest that alcohol use disorder (AUD) may increase the risk of developing AKI, particularly in the subset of AUD patients whose chronic alcohol overuse is sufficient to incur severe liver damage. This subset of AUD patients may also be particularly vulnerable to mortality and increased morbidity upon developing AKI. A recent study looking at the direct link between AUD and AKI specifically in critically ill patients found significantly higher percentages of stages 2-3 AKI in at-risk drinkers vs. non-at-risk drinkers admitted to the ICU [24]. The 3-month survival in patients with alcoholic hepatitis has been shown to significantly decrease upon developing AKI (35\% vs. 93\% in patients without AKI) [17]. Among patients with advanced cirrhosis who initially survive an AKI episode, a significant reduction has been observed in mid-term survival (vs. non-AKI patients) [16,25]. However, it remains unclear if AUD patients are more likely to be diagnosed with $\mathrm{AKI}$ and if they are more likely to develop an advanced stage of AKI (vs. non-AUD patients).

Prevalent overlap between $\mathrm{AKI}$ and AUD motivates this work, which attempts to quantify the relationship between the two conditions in retrospective data from the Medical Information Mart for Intensive Care (MIMIC-III) ICU database [26], as well as an academic hospital that includes patients from across multiple wards.

\section{METHODS}

\subsection{DATASETS}

The analysis presented here utilizes the University of California, San Francisco Medical Center in San Francisco, CA (UCSF) and MIMIC-III databases with minimal preprocessing. Encounters with no raw data, encounters with no age data, and pediatric encounters (age < 18) were excluded. Data collection for UCSF and MIMIC-III datasets was passive and had no impact on patient safety. All data were de-identified in compliance with the Health Insurance Portability and Accountability Act (HIPAA) Privacy Rule. Studies performed on the de-identified data constitute non-human subject studies, and therefore, this study did not require Institutional Review Board approval.

\subsection{DISEASE DEFINITIONS}

We investigated two different methods of encoding AKI: 1) ICD-9 codes (Table 1; used in UCSF and MIMIC-III datasets) and 2) the 2012 Kidney Disease: Improving Global Outcomes scheme (KDIGO; used in MIMIC-III dataset) [27], where stage 2 and stage 3 are considered AKI positive. Stage 2 AKI is defined in the KDIGO staging system as an increase in SCr to more than $200 \%$ to $300 \%$ ( $>2-$ to 3-fold) from baseline or urine output $<0.5 \mathrm{ml} / \mathrm{kg}$ per hour for more than 12 hours [5]. Stage $3 \mathrm{AKI}$ is defined as an increase in SCr to more than $300 \%$ (>3-fold) from baseline, or $\geq 4.0 \mathrm{mg} / \mathrm{dl}$ ( $\geq 354 \mathrm{mmol} / \mathrm{l})$ with an acute increase of at least $0.5 \mathrm{mg} / \mathrm{dl}(44$ $\mathrm{mmol} / \mathrm{L})$, or renal replacement therapy $(\mathrm{RRT})$, or a decrease in estimated glomerular filtration rate (eGFR) to < $35 \mathrm{ml} / \mathrm{min}$ per $1.73 \mathrm{~m}^{2}$ (if $<18$ years of age), or urine output $<0.5 \mathrm{~mL} / \mathrm{kg} / \mathrm{hr}$ for $\geq 24$ hours or anuria for $\geq 12$ hours [5]. In addition to the AUD subpopulation, we also present analysis for the hepatorenal syndrome (HRS) and alcohol-related cirrhosis subpopulations. ICD-9 codes used for generating these subpopulations are listed in Table 1.

Table 1. ICD-9 codes used to identify diagnoses for alcohol-related conditions and acute kidney injury.

\begin{tabular}{|l|l|}
\hline & \multicolumn{1}{|c|}{ ICD-9 codes } \\
\hline Acute Kidney Injury & $790.6,593.9,584.5-584.9$ \\
\hline Alcohol Use Disorder & $291,305.0,303.0,303.9,357.5,425.5,535.3,571.0-571.3,655.4,760.71$ \\
\hline Hepatorenal Syndrome & 572.4 \\
\hline Alcohol-Related Cirrhosis & 571.2 \\
\hline
\end{tabular}


medRxiv preprint doi: https://doi.org/10.1101/2020.01.10.20017061; this version posted January 16 , 2020. The copyright holder for this preprint (which was not certified by peer review) is the author/funder, who has granted medRxiv a license to display the preprint in perpetuity. All rights reserved. No reuse allowed without permission.

\subsection{ALCOHOL USE DISORDER AND ACUTE KIDNEY INJURY CORRELATIONS}

To quantify the relationship between acute kidney injury (AKI) and alcohol use disorder (AUD) in the MIMIC-III and UCSF datasets, we investigated the following three potential interactions:

Disease burden: We investigated the relative prevalence of AKI inside of and outside of the AUD subpopulation, or hepatorenal syndrome, or alcohol-related cirrhosis populations (designated Alcohol-Related Conditions (ARCs)) in the MIMIC-III and UCSF datasets. If AKI is linked to AUD in a substantive way, one would expect to see AKI as more likely to occur in the AUD (or the other ARCs) subpopulation than the non-AUD subpopulation. We examine this interaction between AKI and AUD using both ICD-9 and KDIGO encodings of AKI.

Mortality burden: We investigated the relative mortality rates associated with AKI inside of and outside of the AUD subpopulation (or hepatorenal syndrome or alcohol-related cirrhosis) in the MIMIC-III and UCSF datasets. If AUD exacerbates AKI in a substantive way, one would expect to see mortality rates higher in the subpopulation which has both AKI and AUD than in the subpopulation which only has AKI.

We also performed the mortality burden experiment on analysis subpopulations controlled for patient severity. Patients who have ARCs may be predisposed to worsened mortality outcomes. To control for this potential confounding effect, we downsampled our analysis subpopulations such that the distributions of severity among the subpopulations are equivalent. Patient severity was defined in two ways; using MEWS scores and using the number of unique ICD-9 diagnoses present. If AUD exacerbates AKI in a substantive way, one would expect to see mortality rates higher in the subpopulation which has both AKI and AUD than in the subpopulation which only has AKI.

Disease progression: We investigated the relative disease progression of AKI inside of and outside of the AUD subpopulation (or hepatorenal syndrome or alcohol-related cirrhosis) in the MIMIC-III dataset. Disease progression is defined here as moving from KDIGO stage 1 to stage 2, or from stage 2 to stage 3 . If AUD exacerbates AKI in a substantive way, one would expect to see AKI progress to a higher level of severity more often in patients with AUD.

\section{RESULTS}

\subsection{DISEASE BURDEN}

Population-level baseline incidence rates for the ARCs and AKI differ between the MIMIC-III and UCSF datasets (as shown in Table 2). This likely reflects the differing compositions of the two datasets, as MIMIC-III is comprised of ICU patients and UCSF is mixed-ward. In the MIMIC-III dataset for both the ICD-9 and KDIGO encodings of AKI, there are notable differences in the prevalence of AKI in the AUD (or the other ARCs) and non-AUD subpopulations. In the ICD-9 encoding of AKI, whereas the non-AUD subpopulation reported AKI prevalence of $24.88 \%$, the AUD subpopulation reported a prevalence of $35.94 \%$. We observed a similar difference for the KDIGO encoding: $27.99 \%$ to $39.84 \%$, as shown in Figure 1 and Table 3 . In the UCSF dataset we observed a much larger difference in the prevalence of AKI in the AUD (or the other ARCs) versus non-AUD subpopulations (as shown in Figure 2 and Table 4). The AKI prevalence in the non-ARC subpopulations is consistent across different ARCs, because these ARCs represent a small fraction of the overall population. 
medRxiv preprint doi: https://doi.org/10.1101/2020.01.10.20017061; this version posted January 16, 2020. The copyright holder for this preprint (which was not certified by peer review) is the author/funder, who has granted medRxiv a license to display the preprint in perpetuity.

All rights reserved. No reuse allowed without permission.

Table 2. Population demographics for the MIMIC-III and UCSF datasets, filtered according to our exclusion criteria. Incidence rates of alcohol-related conditions (ARCs) are determined using ICD-9 coding.

\begin{tabular}{|c|c|c|}
\hline Demographics & MIMIC-III & UCSF \\
\hline Age, median (IQR) & $65(53,78)$ & $55(38,67)$ \\
\hline \multicolumn{3}{|l|}{ Age (years) } \\
\hline $18-29$ & $4.32 \%$ & $11.65 \%$ \\
\hline $30-39$ & $4.99 \%$ & $15.21 \%$ \\
\hline $40-49$ & $9.77 \%$ & $12.99 \%$ \\
\hline $50-59$ & $17.87 \%$ & $18.56 \%$ \\
\hline $60-69$ & $22.76 \%$ & $21.17 \%$ \\
\hline $70+$ & $40.28 \%$ & $20.43 \%$ \\
\hline \multicolumn{3}{|l|}{ Sex } \\
\hline female & $43.78 \%$ & $54.61 \%$ \\
\hline male & $56.22 \%$ & $45.39 \%$ \\
\hline $\begin{array}{l}\text { Length of stay, median } \\
\text { (IQR) }\end{array}$ & $1(1,3)$ & $4(2,7)$ \\
\hline \multicolumn{3}{|l|}{$\begin{array}{l}\text { Length of stay, duration } \\
\text { (days) }\end{array}$} \\
\hline $0-2$ & $67.19 \%$ & $32.57 \%$ \\
\hline $3-5$ & $18.32 \%$ & $18.32 \%$ \\
\hline $6-8$ & $5.97 \%$ & $19.93 \%$ \\
\hline $9-11$ & $2.92 \%$ & $5.85 \%$ \\
\hline $12+$ & $5.60 \%$ & $11.92 \%$ \\
\hline $\begin{array}{l}\text { In-hospital mortality } \\
\text { rate }\end{array}$ & $8.50 \%$ & $2.23 \%$ \\
\hline $\begin{array}{l}\text { Alcohol use disorder } \\
\text { (AUD) incidence }\end{array}$ & $4.18 \%$ & $0.85 \%$ \\
\hline $\begin{array}{l}\text { Hepatorenal syndrome } \\
\text { (HRS) incidence }\end{array}$ & $0.99 \%$ & $0.23 \%$ \\
\hline $\begin{array}{l}\text { Alcohol-related } \\
\text { cirrhosis incidence }\end{array}$ & $2.81 \%$ & $0.66 \%$ \\
\hline AKI incidence & $30.76 \%$ & $8.79 \%$ \\
\hline
\end{tabular}


medRxiv preprint doi: https://doi.org/10.1101/2020.01.10.20017061; this version posted January 16, 2020. The copyright holder for this preprint (which was not certified by peer review) is the author/funder, who has granted medRxiv a license to display the preprint in perpetuity.

All rights reserved. No reuse allowed without permission.

Table 3. Prevalence of AKI in subpopulations in the MIMIC-III dataset with and without alcohol use disorder (AUD), hepatorenal syndrome (HRS) and alcohol-related cirrhosis. Results are listed for the two AKI-encoding methods used in this study.

\begin{tabular}{|r|c|c|c|c|}
\hline & \multicolumn{3}{|c|}{ Encoding } & \multicolumn{2}{c|}{ KDIGO } \\
\hline $\begin{array}{l}\text { Alcohol-related } \\
\text { condition (ARC) }\end{array}$ & $\begin{array}{c}\text { ARC } \\
\text { with AKI (\%) }\end{array}$ & $\begin{array}{c}\text { No ARC with } \\
\text { AKI (\%) }\end{array}$ & $\begin{array}{c}\text { ARC } \\
\text { with AKI (\% }\end{array}$ & $\begin{array}{c}\text { No ARC with } \\
\text { AKI (\%) }\end{array}$ \\
\hline AUD & 48.59 & 29.99 & 39.84 & 27.99 \\
\hline HRS & 97.18 & 30.1 & 91.53 & 27.85 \\
\hline Cirrhosis & 59.2 & 29.94 & 49.8 & 27.87 \\
\hline
\end{tabular}

A. Percentage of ICD-9-encoded AKI patients with alcohol-related condition

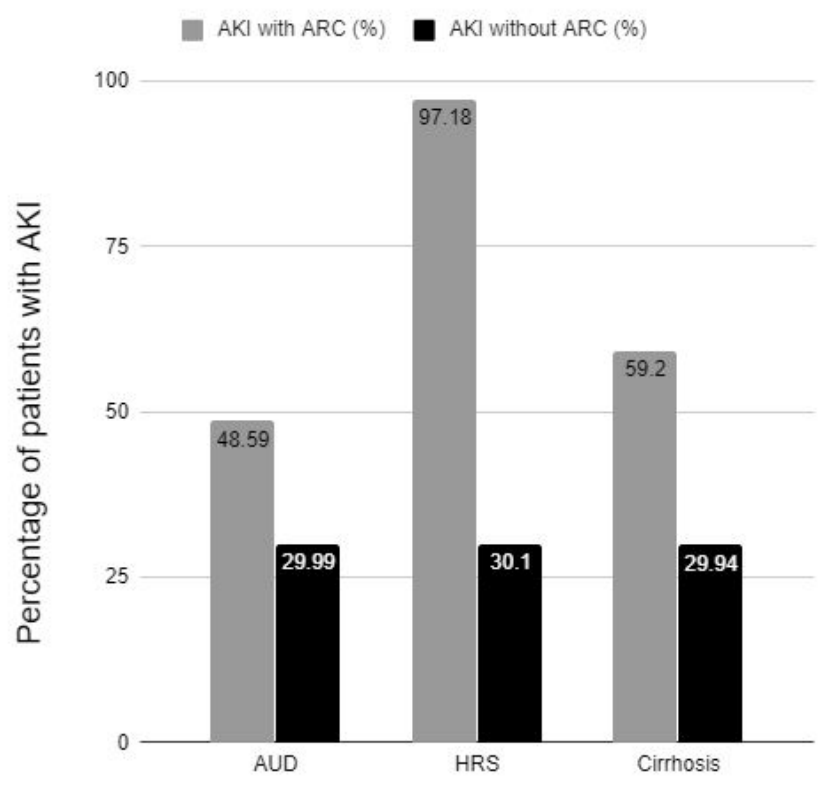

B. Percentage of KDIGO-encoded AKI patients with alcohol-related condition

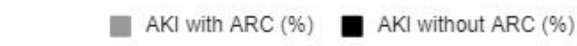

100

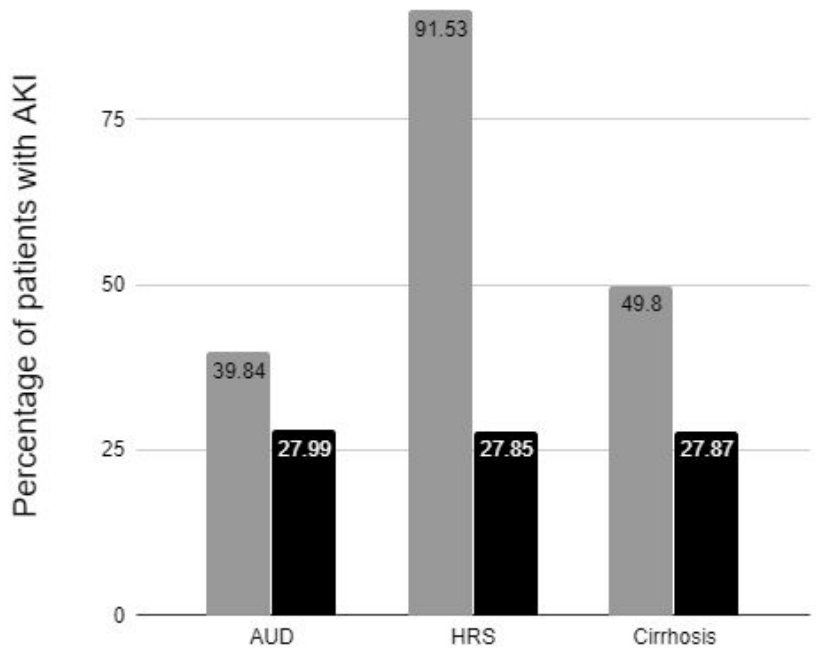

Figure 1. Comparison of AKI prevalence in the MIMIC-III dataset in subpopulations with and without alcohol use disorder (AUD), hepatorenal syndrome (HRS) and alcohol-related cirrhosis, with A. ICD-9-encoded and B. KDIGO-encoded AKI. ARC, alcohol-related condition.

Table 4. Prevalence of AKI (as encoded by ICD-9 codes) in subpopulations in the UCSF dataset with and without alcohol use disorder (AUD), hepatorenal syndrome (HRS) and alcohol-related cirrhosis.

\begin{tabular}{|r|c|c|}
\hline $\begin{array}{l}\text { Alcohol-related } \\
\text { condition (ARC) }\end{array}$ & $\begin{array}{c}\text { ARC } \\
\text { with AKI (\%) }\end{array}$ & $\begin{array}{c}\text { No ARC with } \\
\text { AKI (\%) }\end{array}$ \\
\hline AUD & 48.60 & 8.45 \\
\hline HRS & 95.07 & 8.59 \\
\hline Cirrhosis & 52.34 & 8.5 \\
\hline
\end{tabular}




\section{Percentage of ICD-9-encoded AKI patients with alcohol-related conditions}

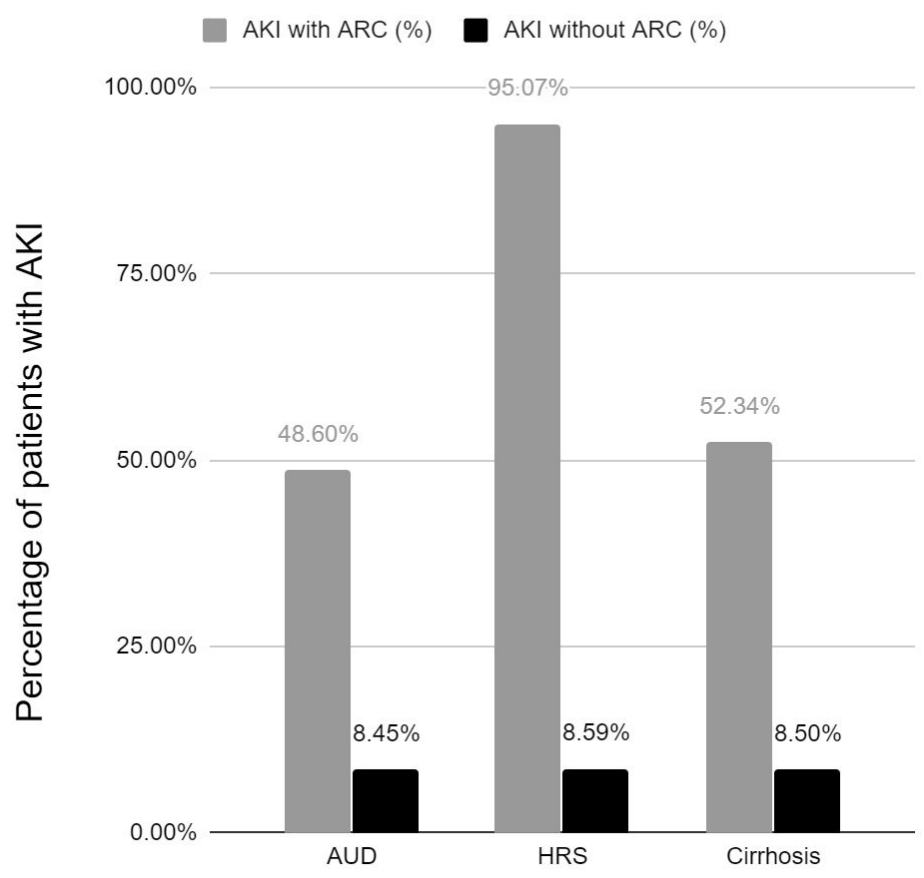

Figure 2. Comparison of ICD-9 encoded AKI prevalence in the UCSF dataset in subpopulations with and without alcohol use disorder (AUD), hepatorenal syndrome (HRS) and alcohol-related cirrhosis. ARC, alcohol-related condition.

\subsection{MORTALITY BURDEN}

For each of the Alcohol-Related Conditions (ARCs) we chose for this experiment (AUD, HRS, alcohol-related cirrhosis), we observed that the mortality rate of the subpopulation with both AKI and the ARC was consistently higher than that of the subpopulation with AKI but not the ARC, as shown in Figure $\mathbf{3}$ and Table $\mathbf{5}$ for the MIMIC-III dataset and Figure 4 and Table 6 for the UCSF dataset. In the MIMIC-III dataset, as seen in the $\mathrm{KDIGO}$-encoded $\mathrm{AKI}$, there was more variance in the difference in mortality rate between the subpopulations that had AKI without the ARC and those that had the ARC without AKI; the mortality rate of the AUD/non-AKI subpopulation (14.99\%) was significantly lower than that of the AKI/non-AUD subpopulation (40.53\%), but for the HRS condition the HRS/non-AKI subpopulation had the higher mortality rate $(46.67 \%$ to $40.42 \%$, Table 4$)$. This suggests that while AUD does seem to interact with AKI to produce increased mortality rates, the relationship between AKI, these ARCs, and mortality rate is complex. Given that alcohol abuse may cause conditions such as alcohol-related cirrhosis [16] or alcohol-related hepatitis [17,18], which in turn causes patients to be more vulnerable to AKI [19], these entangled relational links complicate the relationship between AKI, AUD, and mortality. 
medRxiv preprint doi: https://doi.org/10.1101/2020.01.10.20017061; this version posted January 16, 2020. The copyright holder for this preprint (which was not certified by peer review) is the author/funder, who has granted medRxiv a license to display the preprint in perpetuity. All rights reserved. No reuse allowed without permission.

A. Mortality increase of ICD-9-encoded AKI patients with alcohol-related condition

25

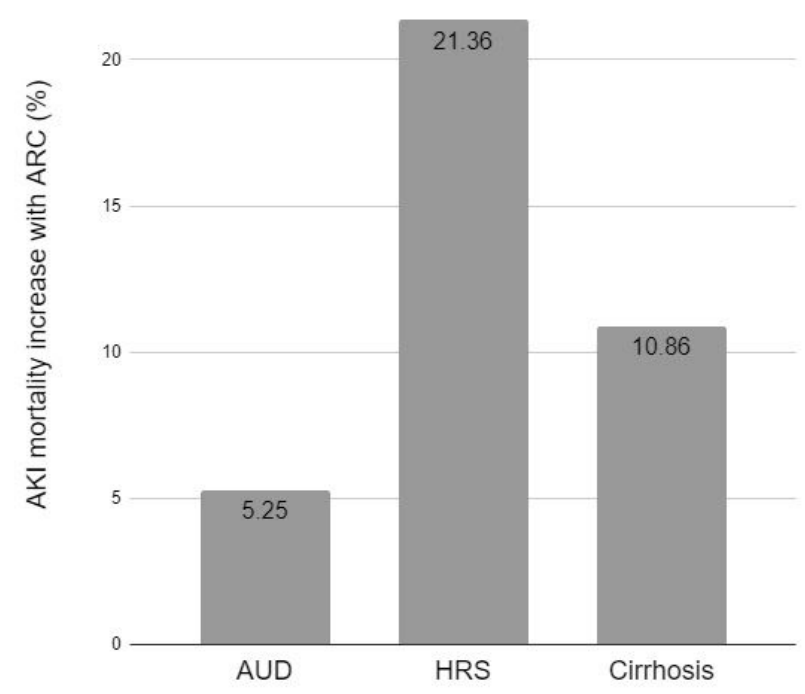

B. Mortality increase of KDIGO-encoded AKI patients with alcohol-related condition

20

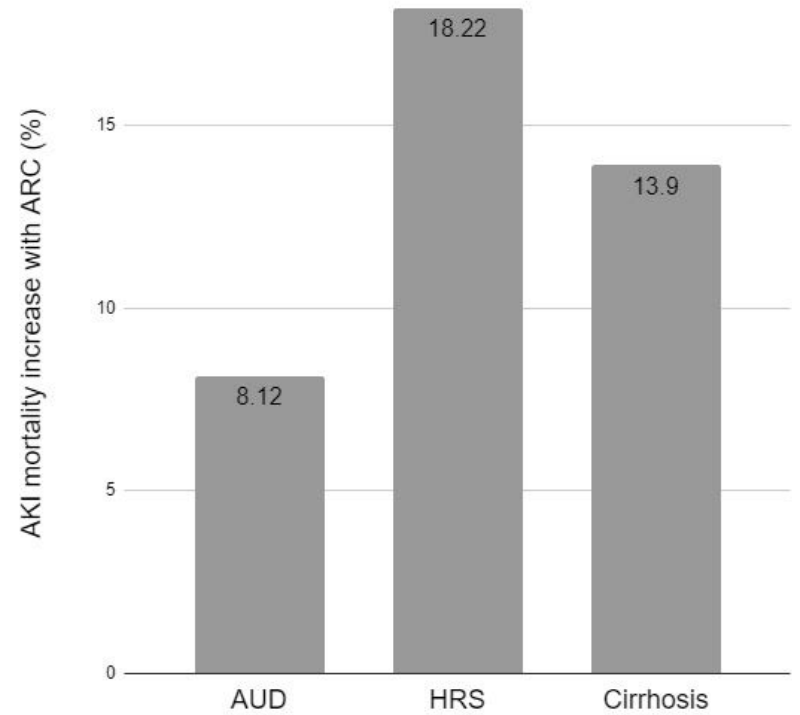

Figure 3. Increase in mortality rates in AKI patients in the MIMIC-III dataset with alcohol use disorder (AUD), hepatorenal syndrome (HRS) and alcohol-related cirrhosis, with A. ICD-9 encoded and B. KDIGO-encoded AKI. ARC, alcohol-related condition.

Table 5. Mortality rates for four subpopulations in the MIMIC-III dataset: 1) with both AKI and the indicated alcohol-related condition (ARC), 2) with the ARC but not AKI, 3) with AKI but not the ARC, and 4) with neither AKI nor the ARC.

\begin{tabular}{|l|c|c|c|c|}
\hline ICD-9 encoding of AKI & $\begin{array}{c}\text { ARC with AKI } \\
(\%)\end{array}$ & $\begin{array}{c}\text { ARC without AKI } \\
(\%)\end{array}$ & $\begin{array}{c}\text { AKI without ARC } \\
(\%)\end{array}$ & $\begin{array}{c}\text { Neither AKI nor ARC } \\
\text { (\%) }\end{array}$ \\
\hline AUD & 42.94 & 14.66 & 37.69 & 16.85 \\
\hline HRS & 58.72 & 20.00 & 37.36 & 16.78 \\
\hline Cirrhosis & 48.31 & 24.02 & 37.45 & 16.66 \\
\hline KDIGO encoding of AKI & \multicolumn{5}{|c|}{} \\
\hline & $\begin{array}{c}\text { ARC with AKI } \\
(\%)\end{array}$ & $\begin{array}{c}\text { ARC without AKI } \\
(\%)\end{array}$ & $\begin{array}{c}\text { AKI without ARC } \\
\text { (\%) }\end{array}$ & $\begin{array}{c}\text { Neither AKI nor ARC } \\
\text { (\%) }\end{array}$ \\
\hline AUD & 48.65 & 14.99 & 40.53 & 16.32 \\
\hline HRS & 58.64 & 46.67 & 40.42 & 16.24 \\
\hline Cirrhosis & 54.22 & 22.71 & 40.32 & 16.14 \\
\hline
\end{tabular}




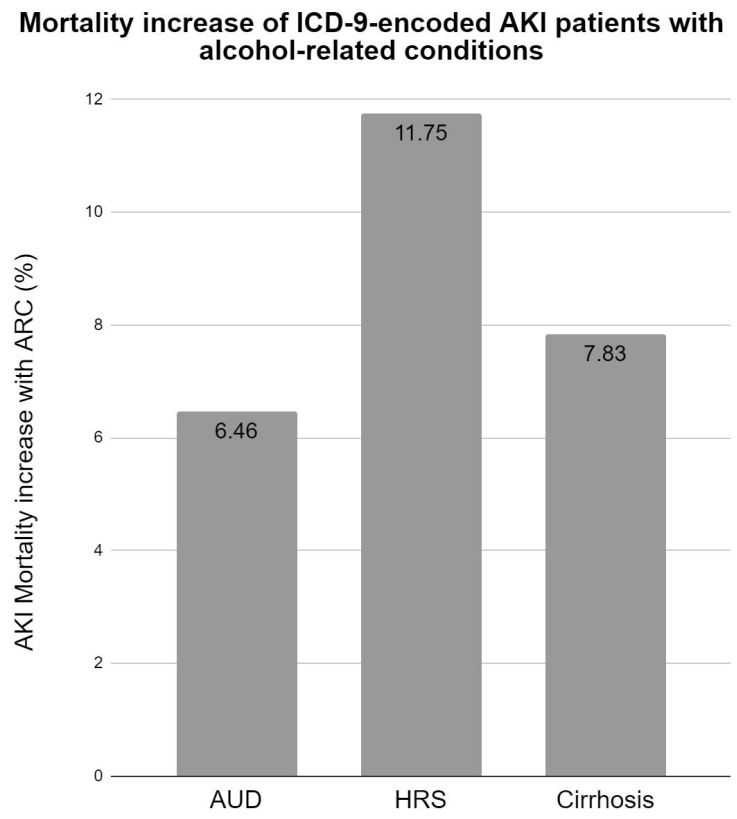

Figure 4. Increase in mortality rates in ICD-9 encoded AKI patients in the UCSF dataset with alcohol use disorder (AUD), hepatorenal syndrome (HRS) and alcohol-related cirrhosis. ARC, alcohol-related condition.

Table 6. Mortality rates for four subpopulations in the UCSF dataset: 1) with both AKI and the indicated alcohol-related condition (ARC), 2) with the ARC but not AKI, 3) with AKI but not the ARC, and 4) with neither AKI nor the ARC.

\begin{tabular}{|l|c|c|c|c|}
\hline ICD-9 encoding of AKI & $\begin{array}{c}\text { ARC with AKI } \\
(\%)\end{array}$ & $\begin{array}{c}\text { ARC without AKI } \\
(\%)\end{array}$ & $\begin{array}{c}\text { AKI without ARC } \\
(\%)\end{array}$ & $\begin{array}{c}\text { Neither AKI nor ARC } \\
\text { (\%) }\end{array}$ \\
\hline AUD & 13.57 & 1.90 & 7.11 & 1.73 \\
\hline HRS & 18.87 & 18.18 & 7.12 & 1.73 \\
\hline Cirrhosis & 14.93 & 2.30 & 7.10 & 1.73 \\
\hline
\end{tabular}

For AUD and alcohol-related cirrhosis, we observed that the mortality rate of the subpopulation with both AKI and the ARC was consistently higher than that of the subpopulation with AKI, but not the ARC, across two methods of severity control (MEWS score and comorbidity count), as shown in Table 7 for the MIMIC-III dataset. For HRS, the subpopulation which had HRS alone experienced the highest mortality rates, though the subpopulation with both HRS and AKI continued to experience higher mortality rates than the subpopulation which had AKI alone.

Table 7. Mortality rates, across two methods of severity control, for four subpopulations in the MIMIC-III dataset: 1) with both $A K I$ and the indicated alcohol-related condition (ARC), 2) with the ARC but not AKI, 3) with AKI but not the ARC, and 4) with neither AKI nor the ARC.

\section{Severity Control Method: \\ MEWS Score}

\begin{tabular}{|l|c|c|c|c|}
\hline & $\begin{array}{c}\text { ARC with AKI } \\
(\mathbf{\%})\end{array}$ & $\begin{array}{c}\text { ARC without AKI } \\
(\mathbf{\%})\end{array}$ & $\begin{array}{c}\text { AKI without ARC } \\
(\mathbf{\%})\end{array}$ & $\begin{array}{c}\text { Neither AKI nor ARC } \\
\text { (\%) }\end{array}$ \\
\hline AUD & 53.39 & 31.78 & 42.79 & 26.03 \\
\hline HRS & 55.56 & 66.39 & 41.52 & 25.89 \\
\hline Cirrhosis & 58.65 & 40.60 & 43.07 & 26.11 \\
\hline
\end{tabular}


medRxiv preprint doi: https://doi.org/10.1101/2020.01.10.20017061; this version posted January 16, 2020. The copyright holder for this preprint (which was not certified by peer review) is the author/funder, who has granted medRxiv a license to display the preprint in perpetuity.

All rights reserved. No reuse allowed without permission.

\begin{tabular}{|c|c|c|c|c|}
\hline \multicolumn{5}{|c|}{$\begin{array}{l}\text { Severity Control Method: } \\
\text { Comorbidity count }\end{array}$} \\
\hline & $\begin{array}{c}\text { ARC with AKI } \\
(\%)\end{array}$ & $\begin{array}{c}\text { ARC without AKI } \\
(\%)\end{array}$ & $\begin{array}{c}\text { AKI without ARC } \\
(\%)\end{array}$ & $\begin{array}{c}\text { Neither AKI nor ARC } \\
(\%)\end{array}$ \\
\hline AUD & 50.00 & 36.82 & 40.67 & 33.32 \\
\hline HRS & 75.00 & 83.33 & 44.89 & 36.72 \\
\hline Cirrhosis & 42.86 & 47.66 & 38.91 & 33.01 \\
\hline
\end{tabular}

\subsection{DISEASE PROGRESSION}

The AKI progression rate for the subpopulation with AUD in the experiment was $19.95 \%$, while the progression rate for the subpopulation without AUD was $18.39 \%$. Similar results were seen in progression rates of the other subpopulations (Table 8). The relatively small difference between the AKI progression rates between these two subpopulations suggests that there is little interaction between AUD and AKI in this domain. We note that the criteria for AUD in the current version of the Diagnostic and Statistical Manual of Mental Disorders (DSM-5) allow for a large degree of heterogeneity in presentation of AUD, and further refinement of the AUD criteria used may yield different results $[10,11]$.

Table 8. AKI progression rates for the subpopulations in the MIMIC-III dataset with and without alcohol use disorder (AUD), hepatorenal syndrome (HRS) and alcohol-related cirrhosis.

\begin{tabular}{|r|c|c|}
\hline $\begin{array}{l}\text { Alcohol-related } \\
\text { condition (ARC) }\end{array}$ & ARC (\%) & No ARC (\%) \\
\hline AUD & 19.95 & 18.39 \\
\hline HRS & 20.00 & 18.43 \\
\hline Cirrhosis & 20.85 & 18.37 \\
\hline
\end{tabular}

\section{DISCUSSION}

Our preliminary work using the MIMIC-III and UCSF datasets show that from a disease burden standpoint, AUD patients have a higher share of AKI than the non-AUD subpopulation, consistent with a previous single-center study that focused on critically ill patients [24]. In our study, the MIMIC-III and UCSF AUD subpopulations had $18.6 \%$ and $40.15 \%$ more AKI patients, respectively, than the non-AUD subpopulations (Tables 3 and 4). This higher share of AKI was even more pronounced for HRS and alcohol-related cirrhosis subpopulations in both datasets, consistent with a prior report on AKI in patients with cirrhosis [1]. In terms of mortality burden, in both datasets we observed that patients with both AKI and AUD or alcohol-related cirrhosis were shown to have higher rates of mortality as compared to AKI patients without these conditions (Figures 3 and 4), and these results were maintained across two methods of disease severity control measurements (Table 7). Our mortality burden results are consistent with previously reported numbers on survival of advanced-cirrhosis patients who develop AKI [16,25]. A disease progression analysis performed on the MIMIC-III dataset indicated that AKI is not more likely to progress from a lower KDIGO stage to a higher KDIGO stage in AUD patients relative to the non-AUD patients (Table 8). Results in the experiments which used both ICD-9 coding and KDIGO encoding of AKI were of similar magnitude in the MIMIC III dataset, regardless of how AKI was defined. 
Several studies have shown that alcohol consumption may provide protection against chronic kidney disease (CKD) $[28,29]$, potentially via bioactivators in alcohols such as red wine, which contains polyphenols that have reactive oxygen species (ROS) scavenging effects which may reduce oxidative stress [30-34]. The multiple mechanisms through which AUD may leave patients vulnerable to AKI include oxidative stress on the kidney, which metabolizes roughly $10 \%$ of consumed ethanol [35]. Alcohol induces production of free radicals [36-40] and also decreases antioxidant capabilities of enzymes in the kidney [41-43]. In a recent comprehensive review on clinical studies looking at links between CKD and alcohol consumption, Fan et al. (2019) concluded that light-to moderate drinking may not have adverse effects on patients with CKD [44]. While the DSM-5 definition of AUD does not quantify alcohol consumption [45], NIAAA defines moderate drinking as "up to 1 drink per day for women and up to 2 drinks per day for men" whereas "binge drinking and heavy alcohol use can increase an individual's risk of alcohol use disorder" [46]. Indeed, a recent study by Pan et al. (2018) found that AUD patients were at an increased risk of developing CKD [47].

While these initial proof-of-concept experiments are based on retrospective datasets, the results provide evidence for the negative influence of AUD on the clinical outcome of AKI. This is consistent with a significant impact of AUD on clinical AKI outcomes, and is worthy of further investigation. In particular, an effect of AUD on AKI-related mortality rates appears to be significant, and further research in this area may be effective and useful. Given that the DSM-5 criteria for AUD allow for a large degree of heterogeneity in presentation $[6,7]$, future studies on the relationship between AKI and AUD could benefit from stratifying the AUD population by AUD severity. The DSM-5 AUD diagnosis requires that patients meet only two of 11 criteria during a 12-month period $[10,11,45]$, making it possible to tabulate severity based on number of criteria met and time since initial diagnosis of AUD.

\section{CONCLUSION}

The results presented in this study augment and quantify existing research suggesting direct links between AUD and AKI. While these results do not determine causation or the mechanisms driving these outcomes, we have observed pronounced relationships between AUD and AKI, which manifested themselves in each of the three alcohol related conditions (ARCs) we studied. In separate datasets with differing compositions and in different encodings of AKI, the presence of AUD and other ARCs was linked to increased AKI and worsened mortality outcomes. However the severity of AKI, represented by progression of AKI along the KDIGO stages, did not present a significant correlation with ARCs. Taken together with existing research, it appears that AUD likely has a negative influence on patients in terms of the risks posed by AKI.

\section{REFERENCES}

1. Garcia-Tsao G, Parikh CR, Viola A. Acute kidney injury in cirrhosis. Hepatology. 2008;48(6):2064-77. doi: 10.1002/hep.22605. PubMed PMID: 19003880.

2. Case J, Khan S, Khalid R, Khan A. Epidemiology of acute kidney injury in the intensive care unit. Critical Care Research and Practice. 2013 Jan 31;13:1-9.

3. Nash K, Hafeez A, Hou S. Hospital Acquired Renal Insufficiency. Am J Kidney Dis. 2002 May; 39: 930-936.

4. Silver SA, Chertow GM. The economic consequences of acute kidney injury. Nephron. 2017 Jun 9. doi:10.1159/000475607. Epub ahead of print

5. Chawla LS, Eggers PW, Star RA, Kimmel PL. Acute kidney injury and chronic kidney disease as interconnected syndromes. New England Journal of Medicine. 2014 Jul 3;371(1):58-66.

6. Kellum JA, Lameire N; KDIGO AKI Guideline Work Group: Diagnosis, evaluation, and management of acute kidney injury: A KDIGO summary (Part 1). Crit Care 2013; 17:204 
medRxiv preprint doi: https://doi.org/10.1101/2020.01.10.20017061; this version posted January 16, 2020. The copyright holder for this preprint (which was not certified by peer review) is the author/funder, who has granted medRxiv a license to display the preprint in perpetuity.

All rights reserved. No reuse allowed without permission.

7. Palevsky PM, Liu KD, Brophy PD, Chawla LS, Parikh CR, Thakar CV, Tolwani AJ, Waikar SS, Weisbord SD. KDOQI US commentary on the $2012 \mathrm{KDIGO}$ clinical practice guideline for acute kidney injury. American Journal of Kidney Diseases. 2013 May 31;61(5):649-72.

8. Rahman M, Shad F, Smith MC. Acute kidney injury: a guide to diagnosis and management. American family physician. 2012 Oct 1;86(7).

9. Keyes R, Bagshaw SM. Early diagnosis of acute kidney injury in critically ill patients. Expert Review of Molecular Diagnostics. 2014 Jan 9;8(4):455-464.

10. https://www.niaaa.nih.gov/alcohol-health/overview-alcohol-consumption/alcohol-use-disorders

11. Grant BF, Goldstein RB, Saha TD, Chou SP, Jung J, Zhang H, Pickering RP, Ruan WJ, Smith SM, Huang B, Hasin DS. Epidemiology of DSM-5 alcohol use disorder: results from the National Epidemiologic Survey on Alcohol and Related Conditions III. JAMA psychiatry. 2015 Aug 1;72(8):757-66.

12. Axley PD, Richardson CT, Singal AK. Epidemiology of Alcohol Consumption and Societal Burden of Alcoholism and Alcoholic Liver Disease. Clin Liv Dis 2019;23(1):39-50.

13. Singal AK, Anad BS. Epidemiology of ALI. Clin Liv Dis 2013;2(2):53-6.

14. Gakidou E, Afshin A, Abajobir AA, et al. Global, regional, and national comparative risk assessment of 84 behavioral, environmental, and occupational, and metabolic risks or clusters of risks, 1990-2016; a systematic analysis for the Global Burden of Disease Study 2016. Lancet 2017;390(10100):1345-422.

15. Varga ZV, Matyas C, Paloczi J, Pacher P. Alcohol misuse and kidney injury: epidemiological evidence and potential mechanisms. Alcohol research: current reviews. 2017;38(2):283.

16. Angeli P, Gines P, Wong F, Bernardi M, Boyer TD, Gerbes A, Moreau R, Jalan R, Sarin SK, Piano S, Moore K, Lee SS, Durand F, Salerno F, Caraceni P, Kim WR, Arroyo V, Garcia-Tsao G. Diagnosis and management of acute kidney injury in patients with cirrhosis: revised consensus recommendations of the International Club of Ascites. J Hepatol. 2015;62(4):968-74. doi: 10.1016/j.jhep.2014.12.029. PubMed PMID: 25638527.

17. Altamirano J, Fagundes C, Dominguez M, Garcia E, Michelena J, Cardenas A, Guevara M, Pereira G, Torres-Vigil $\mathrm{K}$, Arroyo V, Caballeria J, Gines P, Bataller R. Acute kidney injury is an early predictor of mortality for patients with alcoholic hepatitis. Clin Gastroenterol Hepatol. 2012;10(1):65-71 e3. doi: 10.1016/j.cgh.2011.09.011. PubMed PMID: 21946124.

18. Shoreibah M, Anand BS, Singal AK. Alcoholic hepatitis and concomitant hepatitis C virus infection. World J Gastroenterol. 2014;20(34):11929-34. doi: 10.3748/wjg.v20.i34.11929. PubMed PMID: 25232227; PMCID: PMC4161778.

19. Egerod Israelsen M, Gluud LL, Krag A. Acute kidney injury and hepatorenal syndrome in cirrhosis. J Gastroenterol Hepatol. 2015;30(2):236-43. doi: 10.1111/jgh.12709. PubMed PMID: 25160511.

20. European Association For The Study Of The Liver. EASL clinical practice guidelines on the management of ascites, spontaneous bacterial peritonitis, and hepatorenal syndrome in cirrhosis. Journal of Hepatology. 2010 Sep 1;53(3):397-417.

21. Ginès P, Guevara M, Arroyo V, Rodés J. Hepatorenal syndrome. The Lancet. 2003 Nov 29;362(9398):1819-27.

22. Hampel H, Bynum GD, Zamora E, El-Serag HB. Risk factors for the development of renal dysfunction in hospitalized patients with cirrhosis. The American journal of gastroenterology. 2001;96(7):2206-10.

23. Eckardt K-M. Renal failure in liver disease. Intensive care medicine. 1999;25(1):5-14.

24. Gacouin A, Lesouhaitier M, Frerou A, Painvin B, Reizine F, Rafi S, Maamar A, Le Tulzo Y, Tadié JM. At-Risk Drinking Is Independently Associated With Acute Kidney Injury in Critically III Patients. Critical care medicine. 2019 Aug 1;47(8):1041-9.

25. Tsien CD, Rabie R, Wong F. Acute kidney injury in decompensated cirrhosis. Gut. 2013;62(1):131-7.

26. MIMIC-III, a freely accessible critical care database. Johnson AEW, Pollard TJ, Shen L, Lehman L, Feng M, Ghassemi M, Moody B, Szolovits P, Celi LA, and Mark RG. Scientific Data (2016). DOI: 10.1038/sdata.2016.35.

27. Kidney Disease: Improving Global Outcomes (KDIGO) Acute Kidney Injury Work Group. KDIGO clinical practice guideline for acute kidney injury. Kidney Int Suppl. 2012 Feb 7;2(1):1-38.

28. Hu EA, Lazo M, Rosenberg SD, Grams ME, Steffen LM, Coresh J, Rebholz CM. Alcohol consumption and incident kidney disease: results from the atherosclerosis risk in communities study. Journal of Renal Nutrition. 2019 Mar 6.

29. Umesawa M, Sairenchi T, Haruyama Y, Nagao M, Yamagishi K, Irie F, Watanabe H, Kobashi G, Iso H, Ota H. Validity of a risk prediction equation for CKD after 10 years of follow-up in a japanese population: The ibaraki prefectural health study. American Journal of Kidney Diseases. 2018 Jun 1;71(6):842-50.

30. Rezzani R, Tengattini S, Bonomini F et al: Red wine polyphenols prevent cyclosporine-induced nephrotoxicity at the 
medRxiv preprint doi: https://doi.org/10.1101/2020.01.10.20017061; this version posted January 16, 2020. The copyright holder for this preprint (which was not certified by peer review) is the author/funder, who has granted medRxiv a license to display the preprint in perpetuity. All rights reserved. No reuse allowed without permission.

level of the intrinsic apoptotic pathway. Physiol Res, 2009; 58(4): 511-19

31. Boban M, Modun D: Uric acid and antioxidant effects of wine. Croat Med J, 2010; 51(1): 16-22

32. Olas B, Wachowicz B, Tomczak A et al: Comparative anti-platelet and antioxidant properties of polyphenol-rich extracts from: Berries of Aronia melanocarpa, seeds of grape and bark of Yucca schidigera in vitro. Platelets, 2008; 19(1): 70-77

33. Rodrigo R, Bosco $C$, Herrera $P$ et al: Amelioration of myoglobinuric renal damage in rats by chronic exposure to flavonol-rich red wine. Nephrol Dial Transplant, 2004; 19(9): 2237-44

34. Mannari C, Bertelli AA, Stiaccini G et al: Wine, sirtuins and nephroprotection: not only resveratrol. Med Hypotheses, 2010; 75(6): 636-38

35. Adewale A, Ifudu O: Kidney injury, fluid, electrolyte and acid-base abnormalities in alcoholics. Niger Med J, 2014; 55(2): 93-98

36. Shinzawa $\mathrm{M}$, Isaka $\mathrm{Y}$, Iseki $\mathrm{K}$ et al: Ameliorative effects of clonidine on ethanol induced kidney injury in rats: Potential role for imidazoline-1 receptor. Clin Exp Nephrol, 2018; 824: 148-56

37. Hosseini SM, Taghiabadi E, Abnous $\mathrm{K}$ et al: Protective effect of thymoquinone, the active constituent of Nigella sativa fixed oil, against ethanol toxicity in rats. Iran J Basic Med Sci, 2017; 20(8): 927-39

38. Leal S, Ricardo Jorge DO, Joana B et al: Heavy alcohol consumption effects on blood pressure and on kidney structure persist after long-term withdrawal. Kidney Blood Press Res, 2017; 42(4): 664-75

39. Latchoumycandane C, Nagy LE, Mcintyre TM: Myeloperoxidase formation of PAF receptor ligands induces PAF receptor-dependent kidney injury during ethanol consumption. Free Radic Biol Med, 2015; 86: 179-90

40. Latchoumycandane C, Nagy LE, Mcintyre TM: Chronic ethanol ingestion induces oxidative kidney injury through taurine-inhibitable inflammation. Free Radic Biol Med, 2014; 69: 403-16

41. Harris PS, Roy SR, Coughlan $C$ et al: Chronic ethanol consumption induces mitochondrial protein acetylation and oxidative stress in the kidney. Redox Biol, 2015; 6: 33-40

42. Pourbakhsh H, Taghiabadi E, Abnous $\mathrm{K}$ et al: Effect of Nigella sativa fixed oil on ethanol toxicity in rats. Iran J Basic Med Sci, 2014; 17(12): 1020-31

43. Das SK, Varadhan S, Dhanya L et al: Effects of chronic ethanol exposure on renal function tests and oxidative stress in kidney. Indian J Clin Biochem, 2008; 23(4): 341-44

44. Fan Z, Yun J, Yu S, Yang Q, Song L. Alcohol Consumption Can be a "Double-Edged Sword" for Chronic Kidney Disease Patients. Medical science monitor: international medical journal of experimental and clinical research. 2019;25:7059.

45. American Psychiatric Association. Diagnostic and statistical manual of mental disorders (DSM-5®). American Psychiatric Pub; 2013 May 22.

46. https://www.niaaa.nih.gov/alcohol-health/overview-alcohol-consumption/moderate-binge-drinking Accessed 02 Jan 2020

47. an CS, Ju TR, Lee CC, Chen YP, Hsu CY, Hung DZ, Chen WK, Wang IK. Alcohol use disorder tied to development of chronic kidney disease: A nationwide database analysis. PloS one. 2018 Sep 6;13(9):e0203410. 